\title{
MANAGEMENT OF ENDOCRINE DISEASE Present and future perspectives for medical therapy of nonfunctioning pituitary adenomas
}

\section{Yona Greenman}

Institute of Endocrinology, Metabolism and Hypertension, Sackler Faculty of Medicine, Tel Aviv University, Tel Aviv, Israel

\author{
Correspondence \\ should be addressed \\ to $Y$ Greenman \\ Email \\ yonagr@tlvmc.gov.il
}

\begin{abstract}
In contrast to the clear indication for surgical treatment in symptomatic patients with clinically nonfunctioning pituitary adenomas (NFPA), there are no randomized controlled studies comparing therapeutic strategies such as watchful waiting, irradiation or medical therapy for the management of NFPA after surgery. Further, no medical therapy is currently approved for the treatment of NFPA. In this review, we summarize accumulating data on medications currently approved for secreting pituitary adenomas, used off-label in patients with NFPA. Perspectives on overall treatment optimization and potential future therapies are also detailed.
\end{abstract}

\section{Introduction}

Pituitary adenomas are diagnosed as 'nonfunctioning' in the absence of clinical or biochemical evidence of tumor-related hormone excess. Nonfunctioning pituitary adenomas (NFPA) are usually large at diagnosis, presenting with symptoms secondary to mass effects on surrounding tissues, including headaches, visual disturbances and hypopituitarism (1). Surgery is the treatment of choice for decompression of the affected vital structures and rapid symptom amelioration: headaches are resolved in most subjects; visual fields are improved in 80\% and full normalization is achieved in up to $40 \%$ of patients $(2,3)$. Although hypopituitarism per se in not an indication for surgery, post-surgical improvement or normalization of pituitary function reaches $30-70 \%$ in different series $(4,5,6)$.

There are no randomized controlled studies comparing therapeutic strategies such as watchful waiting, irradiation or medical therapy for the management of NFPA after surgery. Further, no medical therapy is currently approved for the treatment of NFPA. In this review, we summarize accumulating data on medications currently approved for secreting pituitary adenomas, used off-label in patients with NFPA. Perspectives on overall treatment optimization and potential future therapies are also detailed.

\section{Invited Author's profile}

Yona Greenman MD is currently a senior lecturer in internal medicine at the Sackler Faculty of Medicine, Tel Aviv University, and the Senior Deputy Director of the Institute of Endocrinology, Metabolism and Hypertension at the Tel Aviv Sourasky Medical Center, Tel Aviv, Israel. Her research focuses on pituitary diseases, neuroendocrine aspects of stress.

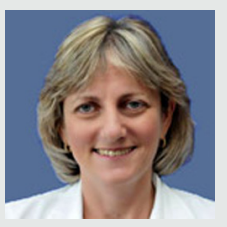

() 2017 European Society of Endocrinology Printed in Great Britain
Published by Bioscientifica Ltd. 


\section{The impact of surgical outcomes on long-term prognosis of NFPA}

Although full resection of these mostly invasive macroadenomas is challenging, it is clear that the presence and size of a residual mass significantly affect the natural history of untreated tumors (7), the need for re-operation or radiation therapy, and the efficacy of additional treatments (8). A recent meta-analysis encompassing 15 studies and 971 patients showed that the recurrence rate for patients without detectable tumor after surgery was $12 \%$, whereas $46 \%$ of the patients with postoperative remnants experienced disease progression, with a mean tumor volume doubling time of 3.4 years (9). Residual tumors with extrasellar extension had a higher progression rate (52.3-66.7\%) compared to remnants confined to the sella $(30-33.3 \%)(7,10,11)$. Hence, the importance of achieving maximal tumor resection cannot be overemphasized, and strategies to achieve this goal should be implemented. The endoscopic, endonasal approach is becoming the technique of choice for pituitary transsphenoidal microsurgery, as it allows better visualization of the operative field (12). Although there are no direct comparisons with the classical microscopic approach (13), improved outcomes have been reported with the use of the endoscope, with greater control of lateral and suprasellar extensions $(14,15)$. Intraoperative Magnetic Resonance Imaging (iMRI) is another valuable modality to maximize tumor resection. A significant increase in 'gross total removal' rates and facilitation of additional mass resection are uniformly reported in studies on iMRI-guided transsphenoidal surgery (16), leading to lower recurrence rates (17). Nevertheless, the Congress of Neurological Surgeons did not recommend its routine use, which is constrained by high costs of the equipment and its installation, prolonged surgical time and possible artifacts (18).

\section{Accurate pathological diagnosis of NFPA - can it affect treatment strategy or choice of medical therapy?}

NFPA comprise a heterogeneous group of lesions, consisting of gonadotropin-secreting tumors, silent adenomas and null cell adenomas (19). The majority belongs to the gonadotroph lineage, based on positive immunostaining for $\beta$-LH and $\beta$-FSH, or, rarely, by the detection of intact gonadotropins or their subunits in the peripheral blood (20). The vast majority of gonadotropin-secreting tumors is silent, presenting with symptoms related to mass effect
(21). Rarely, excessive tumoral FSH secretion may cause menstrual abnormalities and symptoms characteristic of ovarian hyperstimulation syndrome in pre-menopausal women (22). FSH-induced testicular enlargement (23) and LH-induced testosterone hypersecretion (24) are the additional rare presenting symptoms of functioning gonadotropin-secreting tumors.

Approximately $15 \%$ of NFPA arise from other anterior pituitary cells, synthesizing hormones that are detected by immunohistochemistry, but are not significantly secreted, and as such are classified as silent tumors (21). Finally, $44.4 \%$ of over 2000 specimens from the German Pituitary Tumor Registry were classified as null cell adenomas, based on negative immunostaining for all anterior pituitary hormones (25). Using cytogenetic markers, Nishioka et al. recently demonstrated that truly null cell adenomas are in fact rare (26). In the initial routine analysis of 516 NFPA, 58.1\% were classified as gonadotropin-secreting adenomas, 9.9\% were silent corticotroph adenomas, $8.9 \%$ were grouped as other silent tumors (positive staining for $\mathrm{GH}$, prolactin (PRL) or TSH), and $23.1 \%$ stained negative for all hormones. Following staining with antibodies to specific transcription factors including steroidogenic factor-1 (SF-1), estrogen receptor- $\alpha$ (ER- $\alpha)$, pituitary specific transcription factor-1 (Pit-1) and t-box transcription factor (Tpit), 66.4 and $26.9 \%$ of these initially negative tumors were reclassified as belonging respectively to the gonadotroph and the corticotroph lineages (26). Two samples were found to belong to the Pit-1 lineage, and only 6 cases $(5 \%)$ retained the initial diagnosis of null cell adenomas. ACTH-negative, Tpit-positive adenomas had identical clinical features to the ACTH-positive silent corticotroph adenomas in this series, with significant female preponderance, and a higher frequency of giant adenomas and marked cavernous sinus invasion, as compared with gonadotroph-secreting tumors (26).

An accurate pathologic classification is important for risk stratification. Silent corticotroph adenomas (27), as well as silent type 3 adenomas (28), now recognized as poorly differentiated monomorphous plurihormonal Pit-1 lineage adenomas (29), have been generally found to exhibit a more aggressive biological behavior, therefore requiring a more careful follow-up or perhaps a more active therapeutic approach. Further, plurihormonal adenomas were found to have a significantly higher rate of tumor progression after surgery (80\%) in comparison with gonadotropinomas (34\%) (30).

Another question to be explored is whether silent adenomas may respond to treatment in a similar way 
to their lineage specific functional counterparts. The somatostatin and dopamine receptor expression profile of these silent tumors have not been well characterized. In one study, somatostatin receptor (SSTR) 1 mRNA expression was 17-fold higher and SSTR2 mRNA expression was 5-fold higher in silent corticotroph adenomas in comparison with ACTH-secreting tumors (31). On the other hand, SSTR5 mRNA was 15-fold higher in the functional ACTHsecreting tumors compared with the silent adenomas (31), suggesting that the latter may not be good candidates for pasireotide treatment. One silent ACTH tumor that responded to cabergoline treatment with substantial shrinkage was found to have dopamine 2 receptor (D2R) mRNA expression similar to that observed in control prolactinomas (32). Data on SSTR protein expression and response to specific receptor ligands is not available for silent adenomas. Therefore, the possible response of silent ACTH or Tpit expressing tumors to pasireotide or of silent GH, TSH or Pit-1 adenomas to preferential SSTR2 ligands remains to be investigated.

\section{Medical therapy as an alternative to conservative follow-up or radiation therapy in NFPA}

The currently accepted routine postoperative management of NFPA consists of conservative follow-up for most patients, with selective use of radiotherapy (33). Criteria for using either strategy are not well established, although, sensibly, the most aggressive tumors would usually be irradiated in most centers. Both therapeutic options have important drawbacks, which need to be carefully considered:

Conventional radiotherapy has a long record of effectiveness for the postoperative treatment of residual NFPA (10-year actuarial progression-free survival (PFS) of over 90\%) $(34,35)$, but it is associated with a high rate of complications, the most prevalent of which is development of hypopituitarism in over $50 \%$ of patients (36). There is also a lower but not negligible increased risk of visual compromise, secondary brain tumors (37), stroke (38) and possibly neurocognitive or neuropsychological impairment.

Modern stereotactic radiotherapy allows delivery of localized irradiation to the tumor, sparing surrounding normal tissue, thus potentially translating into a better safety profile (39). Recent data are disappointing, in which this premise appears not to hold true. A recent multicenter study under the auspices of the North
American Gamma Knife Consortium based on over 500 patients (40) confirmed treatment efficacy (actuarial PFS of $95 \%$ at five years and $85 \%$ at ten years postradiosurgery), but worsening of a preexisting cranial nerve deficit or development of a new deficit was reported in $9.3 \%$ of patients, mostly involving the optic nerve (6.6\%). Development of hypopituitarism could not be reliably estimated due to a relatively short median follow-up of 36 months. With longer follow-up (median 75 months) the actuarial incidence of new anterior pituitary deficits was $40 \%$ at five years and $72 \%$ at ten years (41), similar to the reported figures for conventional radiation. Hence, even modern radiotherapy techniques are associated with significant side effects, justifying its judicious use with careful selection of patients that may benefit from this treatment, mainly aggressive tumors with high Ki67 proliferation index, deemed to be at a higher risk for tumor progression $(42,43)$.

The alternative to radiation therapy would be conservative follow-up with annual MRI imaging for the detection of tumor progression. This strategy is perfectly adequate for patients who underwent gross total tumor removal, and probably also for those left with minimal or very small tissue remnants, in view of their low rate of recurrence (7). On the other hand, passive observation for patients left with more significant tumor volumes after surgery, are associated with high relapse rates of 23.1, 46.7 and $67.9 \%$ at 5, 10 and 15 years respectively, as reported by Reddy et al. (11). This is a poor outcome, considering that many of these patients will require additional surgery and/or radiotherapy, which have been associated with an elevated standardized mortality ratio (SMR) of 1.65 (1.182.24) (44) in patients with NFPA. Consequently, medical therapy for the prevention of tumor progression in these patients would be of high clinical significance.

\section{Receptor-targeted medical therapy}

\section{Dopamine agonists}

DR expression in most NFPA $(45,46,47)$, constitutes the basis for their targeting with medical agents. Dopamine agonists (DAs) reduced gonadotropin secretion in vitro (48) and in vivo (49) and inhibited thymidine incorporation in two-thirds of NFPA in vitro (50). Bromocriptine induced tumor shrinkage leading to improvement in visual fields, has been reported in small series (51) and case reports (52) now over three decades old. Nevertheless, the effects were modest in comparison to the exuberant effect seen in prolactinomas, hampering the enthusiasm for its use 
on a routine basis. We have proposed a conceptual change in the treatment goal for NFPA, in that stabilization and prevention of tumor growth, rather than tumor shrinkage (53) is sufficient in cases without mass effect on vital structures. In our initial small study, treatment of 33 patients with bromocriptine at a mean dose of $8 \mathrm{mg} /$ day achieved tumor control in $78.8 \%$ of patients, in comparison to $33.3 \%$ in the untreated control group. We have recently published our experience in a larger series of patients, using the long-acting DA cabergoline (54). Seventy-nine patients after partial transsphenoidal resection of NFPA (remnant size $>10 \mathrm{~mm}$ in $80 \%$ of patients) were treated with cabergoline (mean weekly dose: $1.5 \mathrm{mg}$, range: $0.5-3.5 \mathrm{mg}$ ) during a mean period of 8.8 years (range 1-24 years), either following detection of tumor remnant in the first postoperative MRI $(n=55)$, or when there was already evidence for tumor growth during conservative follow-up (remedial treatment, $n=24)$. Preventive treatment resulted in overall tumor control in $87.3 \%$ of patients $(38.2 \%$ tumor shrinkage, $49.1 \%$ tumor stabilization), in comparison with $46.7 \%$ in the untreated control group $(n=60)$. Further, cabergoline treatment induced tumor shrinkage or restraint of tumor growth in over $58 \%$ of patients treated when there was already evidence for active tumor enlargement. The hazards ratio for growth in treatment groups vs control was $0.3(0.16-0.56)$. The fifteen-year PFS rate was 0.805 and 0.24 for the preventive and remedial treatment groups respectively, compared with 0.04 in the control group (Fig. 1). Importantly, the increase in treatmentassociated tumor control detected by imaging translated in improved clinical outcomes, as only $13 \%$ of patients in the preventive treatment group required additional surgery or radiotherapy, compared with $42 \%$ in the control group (54).

Five small studies $(55,56,57,58,59)$ encompassing 54 patients have reported the use of various doses of cabergoline (1-3 mg/week) during short periods (6-12 months) for the treatment of NFPA patients. Despite the small number of patients in each study and the lack of untreated control groups in most of them, the pooled results indicated tumor stabilization in over $80 \%$ of patients, similar to our findings (Table 1). Taken together, DA treatment to prevent tumor remnant growth after surgery seems superior to the currently practiced expectant follow-up. High dose cabergoline-induced valvular heart disease (60) has not been reported with the lower doses used in endocrine disorders (61), thus reducing safety concerns.

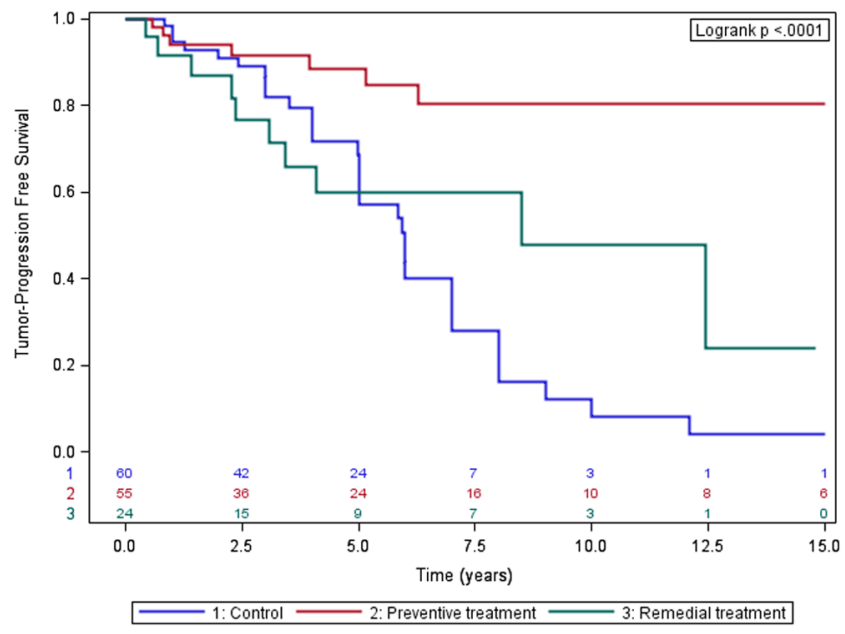

Figure 1

Actuarial tumor progression-free survival in patients with post-operative tumor remnants according to treatment group: Preventive treatment group (PT) - treatment was initiated upon residual tumor detection on postoperative MRI; remedial treatment group (RT) - treatment was initiated upon tumor growth detection during follow-up; control group untreated. At five years: log rank test $P=0.052 ;$ PT vs RT $P=0.045 ; n=$ NS for other comparisons. At 10 years: log rank test $P=0.0002$; control vs PT $P=0.0001$; control vs RT $P=0.06$; PT vs RT $P=0.019$. At 15 years: log rank test $P<0.0001$; control vs PT $P<0.0001$; control vs RT $P=0.039$; PT vs RT $P=0.0053$ (from Ref. (54)).

Surprisingly, tumor response to DA treatment was not related to DR2 protein or mRNA expression in tumor tissue as examined by immunohistochemistry and quantitative RT-PCR (54). Therefore, the surmise that a lesser response to DA treatment in NFPA compared to prolactinomas derives from lower D2R expression levels (62) could not be confirmed by our findings. Further, the expression of $\mathrm{D} 2 \mathrm{R}_{\text {long }}$ and $\mathrm{D} 2 \mathrm{R}_{\text {short }}$ mRNA isoforms in DA resistant prolactinomas was higher than in DA responsive NFPA (54), suggesting that factors additional to $\mathrm{D} 2 \mathrm{R}$ abundance are involved in the clinical response to treatment.

Ideally, a prospective randomized control study should be performed to confirm the effectiveness of cabergoline treatment for NFPA. This would be a challenging endeavor in view of the lack of commercial incentive involved in studying a generic drug, the slow growing nature of these tumors and the lack of serum markers to reflect treatment effectiveness that would necessitate a long follow-up. 
Table 1 Studies on cabergoline treatment of NFPA.

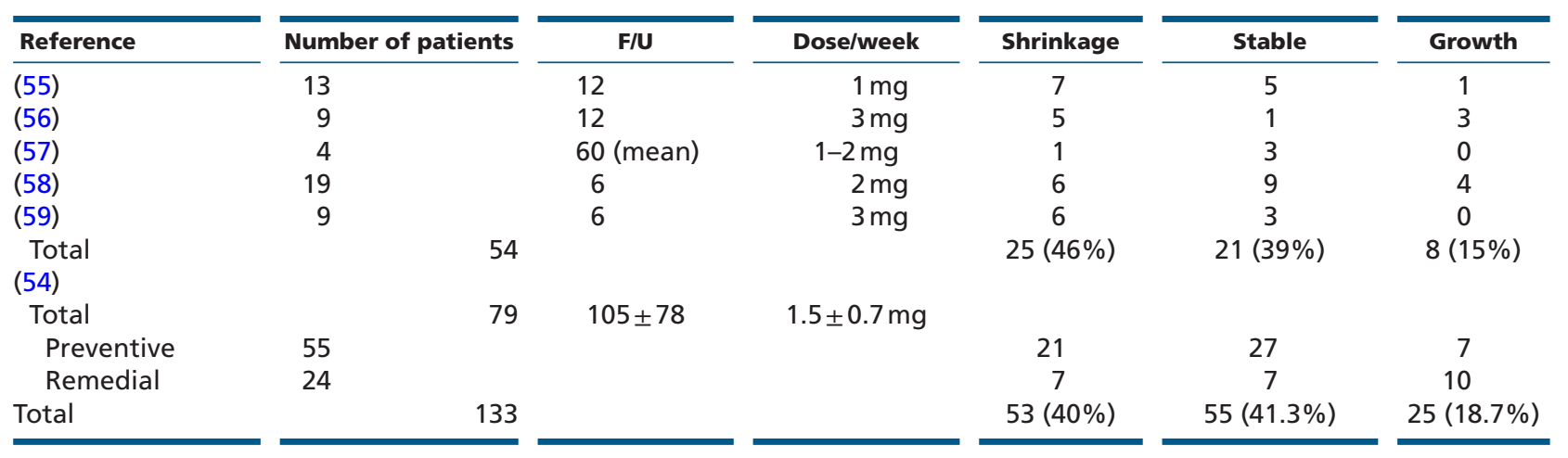

\section{Somatostatin receptor ligands}

Despite the abundant data on somatostatin antisecretory and antiproliferative effects in vitro, the cumulative reported clinical experience with somatostatin receptor ligands (SRLs) for the treatment of NFPA is very sparse. Colao et al. reviewed small uncontrolled studies encompassing 100 patients treated with s.c. octreotide for an average of 6 months (52). Tumor volume decreased in $5 \%$, increased in $12 \%$ and remained unchanged in $83 \%$ of patients. In a case-control study, 26 patients pre-selected by positive tumor uptake in somatostatin receptor scintigraphy were treated with the long-acting somatostatin analog Sandostatin LAR. Tumor size increased in $19 \%$ and remained unchanged in the remaining patients during a mean follow-up time of 37 months (63). It can be concluded that SRL with predominant SSTR2 binding do not effectively induce tumor shrinkage, but long-term well designed studies are necessary to assess their value in controlling tumor growth. When considering SRL for the medical therapy of NFPA, attention should be given to the wide heterogeneity in the SSTR expression pattern in pituitary tumors. The predominant SSTR subtypes expressed in NFPA, SSTR3 and SSTR2 $(64,65)$ correlate with somatostatin inhibition of chromogranin A and glycoprotein $\alpha$-subunit secretion in NFPA cultures (66). SSTR1 (67) and SSTR2 (68), specific analogs have been shown to inhibit NFPA cell proliferation in vitro, but a SSTR5 selective agonist in fact promoted NFPA cell viability (67). Further, a truncated SSTR5 receptor variant, sst5TMD4, associated with aggressive features and resistance to SRL treatment in somatotropinomas, has been detected, albeit with low expression levels, in 50\% of NFPA (69). The effects of sstrTMD4 on NFPA biology and response to treatment remain to be established. The multi-receptor ligand pasireotide reduced NFPA cell viability through the inhibition of vascular endothelium growth factor secretion (70) in a sub-group of tumors characterized by lack of SSTR5 and abundant SSTR3 expression. Predominant SSTR3 expression was confirmed by immunostaining in a large series $(n=118)$ where moderate-to-high SSTR3 expression was found in $83 \%$ of NFPA samples, while only $16 \%$ of cases had this degree of SSTR2 expression (71). Ligand binding of SSTR3 induces p53-associated apoptosis (72), inhibits mitogenic pathways through thyrosine phosphatases activation and suppresses endothelial cell proliferation with resultant anti-angiogenic effects (73). Based on these data, SSTR3 is a promising target for the medical treatment of NFPA. Although pasireotide effectively binds SSTR3, its highest affinity binding to SSTR5 potentially could have untoward effects in selected tumors preferentially expressing this receptor, based on the in vitro study by Zatelli et al. (67). Further, the high number of new cases of impaired glucose metabolism and diabetes reported in patients with Cushing's disease (74) and acromegaly (75) treated with pasireotide would probably not justify its use as a preventive therapy for NFPA tumor stabilization. Nevertheless, if proved effective, it could be of value to control actively growing tumors. The clinical development of selective SSTR3 analogs should be prioritized to advance targeted medical treatment for NFPA.

Combined DA and SRL therapy has been proposed based on enhanced receptor activity secondary to D2R and SSTR5 heterodimerization (76). A somatostatindopamine chimeric compound (BIM-237A760) inhibited thymidine incorporation in $70 \%$ of NFPA in culture, but this response was equivalent to that obtained with the D2R agonist cabergoline (50). The clinical experience of combined therapy is very limited (77), precluding adequate efficacy evaluation. 


\section{GnRH receptor agonists and antagonists}

GnRH desensitization does not occur under chronic $\mathrm{GnRH}$ analog treatment. In fact GnRH analogs cause augmentation of gonadotropin secretion by most tumors, and have no beneficial effect on tumor volume, therefore they are not indicated for the treatment of NFPA (78). Gonadotropin receptor antagonists have been used in a few patients, leading to suppression of gonadotropin secretion, but no effect on tumor size was noted after 3-12 months of treatment (79). A GnRH antagonist was successfully used in a patient bearing a functioning FSH-secreting adenoma who presented with ovarian hyperstimulation (80), leading to reduction in abdominal pain and ovarian volume. Due to limited drug availability, this patient eventually underwent bilateral oophorectomy, as did most patients with sustained ovarian stimulation syndrome whose pituitary tumors could not be effectively controlled with medical treatment or surgical excision (22).

\section{Temozolomide}

Temozolomide (TMZ) is an alkylating agent routinely used for the treatment of malignant gliomas. It has also shown efficacy in metastatic melanomas, neuroendocrine tumors and aggressive pituitary adenomas and carcinomas (81). Roughly one hundred TMZ-treated pituitary tumors have been reported, $35 \%$ of which were carcinomas $(82$, $83,84,85,86)$. Between 46 and $80 \%$ of patients were classified as responders (disease stabilization, complete or partial response) $(84,85,86)$, without a discernible relationship between pituitary tumor type and treatment outcome. NFPA and carcinomas consisted of almost one third of these tumors. Low tumor expression of the DNA repair protein O6-methyl-transferase (MGMT) (86) and immunopositivity of the DNA mismatch repair protein MSH6 (84) have been variably correlated with response to TMZ treatment. Although TMZ is a valuable and maybe the only effective chemotherapeutic agent available for aggressive, progressive and recurrent atypical pituitary adenomas and carcinomas resistant to conventional multimodal treatment, it should be used with caution in view of the lack of controlled trials. Tumor shrinkage or stabilization is usually seen early in the course of treatment, but unfortunately escape and relapse are reported in up to $50 \%$ of patients (84). Strategies to sensitize pituitary cells to TMZ treatment using disulfiram (87), pyrimethamine (88) and HIF-1 $\alpha$ inhibition (89) proved to be effective in vitro in pituitary cell lines, and in xenograft tumorbearing mice models.

\section{Investigational therapies}

\section{Somatostatin receptor-mediated drug targeting}

Peptide receptor radionuclide therapy (PRRT)

PRRT with radiolabeled somatostatin analogs is an important and routinely used modality for the treatment of metastatic gut neuroendocrine tumors (90). The efficacy of this treatment depends on high somatostatin receptor expression, mainly SSTR2 in the tumoral tissue. PRRT has been used so far in four patients with pituitary tumors, with mixed results $(91,92)$. Still, this is a conceptually promising treatment option for SSTR expressing progressive pituitary tumors resistant to conventional treatment, and deserves further investigation.

\section{Octreotide-mediated tumor-targeted cytotoxic drug delivery}

Potent chemotherapeutic agents such as camptothecin, methotrexate, paclitaxel and doxorubicin have been coupled to SSTR2-preferential somatostatin analogs (93), thus enabling delivery of cytotoxic agents to receptorspecific sites, potentially enhancing antitumor efficacy, while reducing toxic side effects to normal tissue. Although effective in vitro, many drug-somatostatin analog hybrids are prone to hydrolysis of the ester bond linking between the drug and the ligand, thus limiting its use in vivo. A doxorubicin-octreotide bioconjugate using a cleavable disulfide-intercalating linker has been recently shown to have promising applicability. It suppressed ACTH secretion in AtT20 mouse pituitary cells and was cytotoxic in pituitary, pancreatic and breast cancer cell lines (94). The clinical value of this drug for cancer patients or subjects with aggressive pituitary tumors remains to be established.

\section{Folate receptor-mediated drug targeting}

Folic acid receptor alpha (FR- $\alpha$ ) is overexpressed in several tumors of epithelial origin such as breast, endometrial, non-small cell lung and ovarian cancer. In view of the restricted FR- $\alpha$ expression in normal tissues, it is an attractive therapeutic target for delivering tumor-selective drugs (95). Different treatments have been developed including FR- $\alpha$-specific monoclonal antibodies and conjugates of folate with chemotherapeutic agents, which are in early-stage clinical testing for lung and ovarian cancer. FR- $\alpha$ is overexpressed both at the mRNA and protein levels in NFPA but not in normal pituitary or secretory 
pituitary tumors (96), being more abundant in invasive and larger tumors with high Ki-67 proliferation index (97). Folate receptor- $\alpha$ targeted liposomal doxorubicin had antiproliferative, antiinvasive and proapoptotic activity in primary cell cultures derived from patients with NFPA (98), thus potentially being of value for treating aggressive tumors. FR- $\alpha$-expressing NFPA can be detected with ${ }^{99 \mathrm{~m}}$ TcFolate SPECT-CT, thus identifying tumors amenable to folate receptor-targeted therapy (99).

\section{Targeting of PI3K/AKT/mTOR pathway}

The phosphatidyl-inositol 3-kinase/protein kinase B (AKT)/mammalian target of rapamycin (PI3K/AKT/ mTOR) pathway has been found to be overactivated in pituitary adenomas $(100,101)$. NFPAs have high AKT and cyclin D1mRNA expression levels in comparison with other pituitary tumors (100). Further, high phosphorylated AKT levels were associated with early recurrence of NFPA (102), and the expression levels of the mTOR pathway regulator proteins RAPTOR and RICTOR correlated with tumor size and invasiveness (103). Therefore, inhibition of PI3K signaling may be a valuable therapeutic target for pituitary tumors and specifically for NFPA (104). Accumulating in vitro data are encouraging. The mTOR inhibitor everolimus, a derivative of rapamycin, significantly reduced cell viability and promoted apoptosis in NFPA primary cultures (105). The dual PI3K-AKT-mTOR inhibitor NVP-BEZ235 had antiproliferative effects against NFPA both in vitro and in vivo (106). Combination treatment with octreotide decreased AKT phosphorylation and conferred sensitivity to NFPA cells resistant to rapamycin monotherapy, and augmented the antiproliferative effect in rampamycin sensitive cells (107). Unfortunately, the combined use of everolimus and octreotide failed to control an ACTH pituitary carcinoma resistant to TMZ treatment (108). Although promising in preclinical models, the role of mTOR inhibitors for the treatment of NFPA remains to be established.

\section{Clinical issues beyond local tumor control}

Hypopituitarism, repeated surgeries and radiation therapy have all been associated with increased mortality rates and decreased quality of life (QoL) in NFPA patients. Although it is difficult to dissect the individual contributions of these inter-related factors to the adverse outcomes, it is clear that efforts should be made to limit the need for additional invasive interventions with their associated complications, after the initial surgery.

\section{Hypopituitarism}

Hypopituitarism is highly prevalent in patients with NFPA, primarily or secondarily to surgery and/or radiation therapy. In a recent large study from two referral centers in England and Ireland, only $17.2 \%$ of patients remained with intact pituitary function, whereas 9.9, 24.9 and $47.9 \%$ had single or multiple hormone deficiencies and panhypopituitarism respectively (109). Relative mortality rates increased with the severity of pituitary failure and with the presence of ACTH and gonadotropin deficiencies (RR: 2.56 and 2.26 respectively) (109). Importantly, increased hydrocortisone $(109,110)$, and lower levothyroxine doses were associated with increased risk of death. These findings underscore the importance of striving to achieve the most physiologic replacement regimen possible.

\section{Quality of life}

Many $(111,112)$ but not all studies (113) have found decreased QoL in NFPA patients. In more recent studies although the overall QoL was near normal (114), single dimensions (energy, depression, sexual activity and vision) were variably affected $(113,114)$. Hypopituitarism (112), female gender $(112,113)$ and unreplaced male hypogonadism (113) were variables associated with worse QoL. Subjects who received radiotherapy, those who had tumor recurrence and patients who underwent repeated surgery scored worse in areas of energy levels and anxiety (113), underscoring the importance of efficient medical therapies that decrease the need for these interventions.

\section{Mortality}

Standardized mortality rate (SMR) is increased in NFPA. In a large cohort from Oxford the overall SMR was 3.6 (2.9-4.5) (115). Data from Denmark (116) and Sweden (116) revealed a significantly increased mortality rate for women (SMR: 1.97 and 1.37 respectively), but not for men. The increased relative rate of death (1.62) in irradiated patients appears to be secondary to hypopituitarism, as shown by multivariate analysis of the data (109). Improvement in treatment quality (114) and reduction in the prevalence of hypopituitarism (117) are leading to a time trend decrease in SMRs. Main causes of death were 
cardio/cerebrovascular (33.7\%), infections (30.1\%) and malignancy (28.9\%) (115).

\section{Conclusions}

In the absence of randomized controlled trials comparing therapeutic options for the management of NFPA after surgery, electing the most appropriate treatment for the individual patient cannot be based on the principles of evidence-based medicine. Currently, only data derived from observational studies together with our clinical judgment are available to guide our decisions, with the aim of providing the best 'informed based medicine' to our patients. Based on our recent data, DA treatment emerges as an attractive therapy for patients with clinically significant tumor remnants after surgery, in view of its association with superior tumor control and a lesser need for repeated surgery and radiation therapy, compared with conservative follow-up. Although SSTR2selective SRLs appear to be of limited therapeutic value for NFPA, SSTR3-selective ligands may prove to be of superior efficacy, based on limited in vitro data. Radiation therapy remains central for the treatment of aggressive NFPA, and TMZ is the first-choice chemotherapy for tumors with relentless growth despite irradiation. PRRT with radiolabeled somatostatin analogs, folate receptormediated drug targeting and inhibitors of the PI3K/AKT/ mTOR pathway are investigational treatment modalities that may prove effective for tumors resistant to the available agents. Finally, optimal hormonal replacement therapy for patients with hypopituitarism is essential to improve QoL and reduce mortality.

\section{Declaration of interest}

The author declares that there are no conflicts of interest that could be perceived as prejudicing the impartiality of this review.

\section{Funding}

This research did not receive any specific grant from any funding agency in the public, commercial or not-for-profit sector.

\section{References}

1 Greenman Y \& Stern N. Non-functioning pituitary adenomas. Best Practice and Research Clinical Endocrinology and Metabolism 200923 625-638. (doi:10.1016/j.beem.2009.05.005)

2 Losa M, Mortini P, Barzagh R, Ribotto P, Terreni MR, Marzoli SB, Pieralli S \& Giovanelli M. Early results of surgery in patients with nonfunctioning pituitary adenomas and analysis of the risk of tumor recurrence. Journal of Neurosurgery $2008 \mathbf{1 0 8} 525-532$. (doi:10.3171/JNS/2008/108/3/0525)
3 Dekkers OM, Pereira AM, Roelfsema F, Voormolen JH, Neelis KJ, Schroijen MA, Smit JW \& Romijn JA. Observation alone after transsphenoidal surgery for nonfunctioning pituitary macroadenoma. Journal of Clinical Endocrinology and Metabolism 200691 1796-1801. (doi:10.1210/jc.2005-2552)

4 Nomikos P, Ladar C, Fahlbusch R \& Buchfelder M. Impact of primary surgery on pituitary function in patients with nonfunctioning pituitary adenomas - a study on 721 patients. Acta Neurochirurgica 2004146 27-35. (doi:10.1007/s00701-003-0174-3)

5 Greenman Y, Tordjman K, Kisch E, Razon N, Ouaknine G \& Stern N. Relative sparing of anterior pituitary function in patients with growth hormone-secreting macroadenomas: comparison with nonfunctioning macroadenomas. Journal of Clinical Endocrinology and Metabolism 199580 1577-1583. (doi:10.1210/jc.80.5.1577)

6 Webb SM, Rigla M, Wägner A, Oliver B \& Bartumeus F. Recovery of hypopituitarism after neurosurgical treatment of pituitary adenomas. Journal of Clinical Endocrinology and Metabolism 1999 84 3696-3700. (doi:10.1210/jcem.84.10.6019)

7 Greenman Y, Ouaknine G, Veshchev I, Reider-Groswasser II, Segev Y \& Stern N. Postoperative surveillance of clinically nonfunctioning pituitary macroadenomas: markers of tumour quiescence and regrowth. Clinical Endocrinology 200358 763-769. (doi:10.1046/j.1365-2265.2003.01784.x)

8 Sheehan JP, Starke RM, Mathieu D, Young B, Sneed PK, Chiang VL, Lee JY, Kano H, Park KJ, Niranjan A et al. Gamma Knife radiosurgery for the management of nonfunctioning pituitary adenomas: a multicenter study. Journal of Neurosurgery 2013119 446-456. (doi:10.3171/2013.3.JNS12766)

9 Chen Y, Wang CD, Su ZP, Chen YX, Cai L, Zhuge QC \& $\mathrm{Wu} \mathrm{ZB}$. Natural history of postoperative nonfunctioning pituitary adenomas: a systematic review and meta-analysis. Neuroendocrinology 201296 333-342. (doi:10.1159/000339823)

10 O'Sullivan EP, Woods C, Glynn N, Behan LA, Crowley R, O'Kelly P, Smith D, Thompson CJ \& Agha A. The natural history of surgically treated but radiotherapy-naïve nonfunctioning pituitary adenomas. Clinical Endocrinology 200971 709-714. (doi:10.1111/j.1365-2265.2009.03583)

11 Reddy R, Cudlip S, Byrne JV, Karavitaki N \& Wass JA. Can we ever stop imaging in surgically treated and radiotherapy-naive patients with non-functioning pituitary adenoma? European Journal of Endocrinology 2011165 739-744. (doi:10.1530/EJE-11-0566)

12 Jho HD. Endoscopic transsphenoidal surgery. Journal of Neurooncology 200154 187-195. (doi:10.1023/A:1012969719503)

13 Zhang X, Fein Z, Zhang J, Fu L, Zhang Z, Liu W \& Chen Y. Management of nonfunctioning pituitary adenomas with suprasellar extensions by transsphenoidal microsurgery. Surgical Neurology 199952 380-385. (doi:10.1016/S0090-3019(99)00120-2)

14 McLaughlin N, Eisenberg AA, Cohan P, Chaloner CB \& Kelly DF. Value of endoscopy for maximizing tumor removal in endonasal transsphenoidal pituitary adenoma surgery. Journal of Neurosurgery 2013118 613-620. (doi:10.3171/2012.11.JNS112020)

15 Messerer M, De Battista JC, Raverot G, Kassis S, Dubourg J, Lapras V, Trouillas J, Perrin G \& Jouanneau E. Evidence of improved surgical outcome following endoscopy for nonfunctioning pituitary adenoma removal. Neurosurgery Focus 201130 E11. (doi:10.3171/2011.1.FOCUS10308)

16 Buchfelder M \& Schlaffer SM. Intraoperative magnetic resonance imaging for pituitary adenomas. Frontiers in Hormone Research 201645 121-132. (doi:10.1159/000442328)

17 Berkmann S, Schlaffer S, Nimsky C, Fahlbusch R \& Buchfelder M. Follow-up and long-term outcome of nonfunctioning pituitary adenoma operated by transsphenoidal surgery with intraoperative high-field magnetic resonance imaging. Acta Neurochirurgica 2014 156 2233-2243. (doi:10.1007/s00701-014-2210-x)

18 Kuo JS, Barkhoudarian G, Farrell CJ, Bodach ME, Tumialan LM, Oyesiku NM, Litvack Z, Zada G, Patil CG \& Aghi MK. Congress 
of neurological surgeons systematic review and evidencebased guideline on surgical techniques and technologies for the management of patients with nonfunctioning pituitary adenomas. Neurosurgery 201679 E536-E538. (doi:10.1227/ NEU.0000000000001390)

19 Al-Shraim M \& Asa SL. The 2004 World Health Organization classification of pituitary tumors: what is new? Acta Neuropathologica 2006111 1-7. (doi:10.1007/s00401-005-1093-6)

20 Somjen D, Tordjman K, Kohen F, Baz M, Razon N, Ouaknine $\mathrm{G} \&$ Stern N. Combined $\beta \mathrm{FSH}$ and $\beta \mathrm{LH}$ response to TRH in patients with clinically non-functioning pituitary adenomas. Clinical Endocrinology 199746 555-562. (doi:10.1046/j.13652265.1997.1720986.x)

21 Cooper O \& Melmed S. Subclinical hyperfunctioning pituitary adenomas: the silent tumors. Best Practice and Research Clinical Endocrinology and Metabolism 201226 447-460. (doi:10.1016/j. beem.2012.01.002)

22 Halupczok J, Kluba-Szyszka A, Bidzińska-Speichert B \& Knychalski B. Ovarian hyperstimulation caused by gonadotroph pituitary adenoma-review. Advances in Clinical and Experimental Medicine 201524 695-703. (doi:10.17219/acem/25212)

23 Dahlqvist P, Koskinen LO, Brännström T \& Hägg E. Testicular enlargement in a patient with a FSH-secreting pituitary adenoma. Endocrine 201037 289-293. (doi:10.1007/s12020-009-9302-z)

24 Chamoun R, Layfield L \& Couldwell WT. Gonadotroph adenoma with secondary hypersecretion of testosterone World Neurosurgery 201380 900.e7-900.e11. (doi:10.1016/j.wneu.2012.11.069)

25 Saeger W, Lüdecke DK, Buchfelder M, Fahlbusch R, Quabbe HJ \& Petersenn S. Pathohistological classification of pituitary tumors: 10 years of experience with the German Pituitary Tumor Registry. European Journal of Endocrinology 2007156 203-216. (doi:10.1530/ eje.1.02326)

26 Nishioka H, Inoshita N, Mete O, Asa SL, Hayashi K, Takeshita A, Fukuhara N, Yamaguchi-Okada M, Takeuchi Y \& Yamada S. The complementary role of transcription factors in the accurate diagnosis of clinically nonfunctioning pituitary adenomas. Endocrine Pathology 201526 349-355. (doi:10.1007/s12022-0159398-z)

27 Bradley KJ, Wass JA \& Turner HE. Non-functioning pituitary adenomas with positive immunoreactivity for ACTH behave more aggressively than ACTH immunonegative tumors but do not recur more frequently. Clinical Endocrinology 200358 59-64. (doi:10.1046/j.1365-2265.2003.01674.x)

28 Erickson D, Scheithauer B, Atkinson J, Horvath E, Kovacs K, Lloyd RV \& Young WF Jr. Silent subtype 3 pituitary adenoma: a clinicopathologic analysis of the Mayo Clinic experience. Clinical Endocrinology 200971 92-99. (doi:10.1111/j.13652265.2008.03514.x)

29 Mete O, Gomez-Hernandez K, Kucharczyk W, Ridout R, Zadeh G, Gentili F, Ezzat S \& Asa SL. Silent subtype 3 pituitary adenomas are not always silent and represent poorly differentiated monomorphous plurihormonal Pit-1 lineage adenomas. Modern Pathology 201629 131-142. (doi:10.1038/modpathol.2015.151)

30 Brochier S, Galland F, Kujas M, Parker F, Gaillard S, Raftopoulos C, Young J, Alexopoulou O, Maiter D \& Chanson P. Factors predicting relapse of nonfunctioning pituitary macroadenomas after neurosurgery: a study of 142 patients. European Journal of Endocrinology 2010163 193-200. (doi:10.1530/EJE-10-0255)

31 Tateno T, Kato M, Tani Y, Oyama K, Yamada S \& Hirata Y. Differential expression of somatostatin and dopamine receptor subtype genes in adrenocorticotropin (ACTH)-secreting pituitary tumors and silent corticotroph adenomas. Endocrine Journal 2009 56 579-584. (doi:10.1507/endocrj.K08E-186)

32 Petrossians P, Ronci N, Valdés Socin H, Kalife A, Stevenaert A, Bloch B, Tabarin A \& Beckers A. ACTH silent adenoma shrinking under cabergoline. European Journal of Endocrinology $2001 \mathbf{1 4 4}$ 51-57. (doi:10.1530/eje.0.1440051)

33 Greenman Y \& Stern N. Optimal management of nonfunctioning pituitary adenomas. Endocrine 201550 51-55. (doi:10.1007/s12020-015-0685-8)

34 Gittoes NJ, Bates AS, Tse W, Bullivant B, Sheppard MC, Clayton RN \& Stewart PM. Radiotherapy for non-function pituitary tumours. Clinical Endocrinology 199848 331-337. (doi:10.1046/ j.1365-2265.1998.00393.x)

35 Kanner AA, Corn BW \& Greenman Y. Radiotherapy of nonfunctioning and gonadotroph adenomas. Pituitary 200912 15-22. (doi:10.1007/s11102-008-0089-3)

36 Darzy KH \& Shalet SM. Hypopituitarism as a consequence of brain tumours and radiotherapy. Pituitary 20058 203-211. (doi:10.1007/s11102-006-6042-4)

37 Minniti G, Traish D, Ashley S, Gonsalves A \& Brada M. Risk of second brain tumor after conservative surgery and radiotherapy for pituitary adenomas; update after an additional 10 years. Journal of Clinical Endocrinology and Metabolism 200590 800-804. (doi:10.1210/jc.2004-1152)

38 Erfurth EM, Bulow B, Svahn-Tapper G, Norrving B, Odh K, Mikoczy Z, Björk J \& Hagmar L. Risk factors for cerebrovascular deaths in patients operated and irradiated for pituitary tumors. Journal of Clinical Endocrinology and Metabolism $2002874892-$ 4899. (doi:10.1210/jc.2002-020526)

39 Minniti G, Jaffrain-Rea ML, Osti M, Cantore G \& Enrici RM. Radiotherapy for nonfunctioning pituitary adenomas: from conventional to modern stereotactic radiation techniques. Neurosurgical Review 200730 167-176. (doi:10.1007/s10143-0070072-x)

40 Sheehan JP, Starke RM, Mathieu D, Young B, Sneed PK, Chiang VL, Lee JY, Kano H, Park KJ, Niranjan A et al. Gamma Knife radiosurgery for the management of nonfunctioning pituitary adenomas: a multicenter study. Journal of Neurosurgery 2013119 446-456. (doi:10.3171/2013.3.JNS12766)

41 Minniti G, Scaringi C, Poggi M, Jaffrain Rea ML, Trillò G, Esposito V, Bozzao A, Enrici MM, Toscano V \& Enrici RM. Fractionated stereotactic radiotherapy for large and invasive non-functioning pituitary adenomas: long-term clinical outcomes and volumetric MRI assessment of tumor response. European Journal of Endocrinology 2015172 433-441. (doi:10.1530/EJE-14-0872)

42 Honegger J, Prettin C, Feuerhake F, Petrick M, Schulte-Mönting $\mathrm{J} \&$ Reincke M. Expression of Ki-67 antigen in nonfunctioning pituitary adenomas: correlation with growth velocity and invasiveness. Journal of Neurosurgery 200399 674-679. (doi:10.3171/jns.2003.99.4.0674)

43 Gejman R, Swearingen B \& Hedley-Whyte ET. Role of Ki-67 proliferation index and p53 expression in predicting progression of pituitary adenomas. Human Pathology 200838 758-766. (doi:10.1016/j.humpath.2007.10.004)

44 Olsson DS, Nilsson AG, Bryngelsson IL, Trimpou P, Johannsson $G$ \& Andersson E. Excess mortality in women and young adults with non-functioning pituitary adenoma - a Swedish nationwide study. Journal of Clinical Endocrinology and Metabolism 2015100 2651-2658. (doi:10.1210/jc.2015-1475)

45 Renner U, Arzberger T, Pagotto U, Leimgruber S, Uhl E, Müller A, Lange M, Weindl A \& Stalla GK. Heterogeneous dopamine D2 receptor subtype messenger ribonucleic acid expression in clinically nonfunctioning pituitary adenomas. Journal of Clinical Endocrinology and Metabolism 199883 1368-1375. (doi:10.1210/ jc.83.4.1368)

46 Stefaneanu L, Kovacs K, Horvath E, Buchfelder M, Fahlbusch $\mathrm{R} \&$ Lancranjan L. Dopamine D2 receptor gene expression in human adenohypophysial adenomas. Endocrine 200114 329-336. (doi:10.1385/ENDO:14:3:329) 
47 Neto LV, Machado Ede O, Luque RM, Taboada GF, Marcondes JB, Chimelli LM, Quintella LP, Niemeyer P Jr, de Carvalho DP, Kineman RD et al. Expression analysis of dopamine receptor subtypes in normal human pituitaries, nonfunctioning pituitary adenomas and somatotropinomas, and the association between dopamine and somatostatin receptors with clinical response to octreotide-LAR in acromegaly. Journal of Clinical Endocrinology and Metabolism 200994 1931-1937. (doi:10.1210/jc.2008-1826)

48 Kwekkeboom DJ, Hofland LJ, van Koetsveld PM, Singh R, van den Berge JH \& Lamberts SW. Bromocriptine increasingly suppresses the in vitro gonadotropin and alpha-subunit release from pituitary adenomas during long term culture. Journal of Clinical Endocrinology and Metabolism 199071 718-724. (doi:10.1210/ jcem-71-3-718)

49 Kwekkeboom DJ \& Lamberts SW. Long-term treatment with the dopamine agonist CV 205-502 of patients with a clinically non-functioning, gonadotroph, or alpha-subunit secreting pituitary adenoma. Clinical Endocrinology 199236 171-176. (doi:10.1111/j.1365-2265.1992.tb00953.x)

50 Florio T, Barbieri F, Spaziante R, Zona G, Hofland LJ, van Koetsveld PM, Feelders RA, Stalla GK, Theodoropoulou M, Culler $\mathrm{MD}$ et al. Efficacy of a dopamine-somatostatin chimeric molecule, BIM-23A760, in the control of cell growth from primary cultures of human non-functioning pituitary adenomas: a multi-center study. Endocrine-Related Cancer 200815 583-596. (doi:10.1677) ERC-07-0271)

51 VanSchaadenburg D, Roefselma F, Van Seters AP \& Vielvoye GJ. Bromocriptine therapy for non-functioning pituitary adenoma. Clinical Endocrinology 198930 475-484. (doi:10.1111/j.1365-2265.1989.tb01418.x)

52 Colao A, Di Somma C, Pivonello R, Faggiano A, Lombardi G \& Savastano S. Medical therapy for clinically non-functioning pituitary adenomas. Endocrine-Related Cancer 200815 905-915. (doi:10.1677/ERC-08-0181)

53 Greenman Y, Tordjman K, Osher E, Veshchev I, Shenkerman G, Reider-Groswasser II, Segev Y, Ouaknine G \& Stern N. Postoperative treatment of clinically nonfunctioning pituitary adenomas with dopamine agonists decreases tumour remnant growth. Clinical Endocrinology 200563 39-44. (doi:10.1111/ j.1365-2265.2005.02295.x)

54 Greenman Y, Cooper O, Yaish I, Robenshtok E, Sagiv N, JonasKimchi T, Yuan X, Gertych A, Shimon I, Ram Z et al. Treatment of clinically nonfunctioning pituitary adenomas with dopamine agonists. European Journal of Endocrinology 2016175 63-72. (doi:10.1530/EJE-16-0206)

55 Lohmann T, Trantakis C, Biesold M, Prothmann S, Guenzel S, Schober R \& Paschke R. Minor tumour shrinkage in nonfunctioning pituitary adenomas by long-term treatment with the dopamine agonist cabergoline. Pituitary 20014 173-178. (doi:10.1023/A:1015366923810)

56 Pivonello R, Matrone C, Filippella M, Cavallo LM, Di Somma C, Cappabianca P, Colao A, Annunziato L \& Lombardi G. Dopamine receptor expression and function in clinically nonfunctioning pituitary tumors: comparison with the effectiveness of cabergoline treatment. Journal of Clinical Endocrinology and Metabolism 200489 1674-1683. (doi:10.1210/ jc.2003-030859)

57 de Herder WW, Reijs AE, Feelders RA, van Aken MO, Krenning EP, Tanghe HL, van der Lely AJ \& Kwekkeboom DJ. Dopamine agonist therapy of clinically non-functioning pituitary macroadenomas. Is there a role for 123I-epidepride dopamine D2 receptor imaging? European Journal of Endocrinology 2006155 717-723. (doi:10.1530/ eje.1.02281)

58 Garcia EC, Naves LA, Silva AO, de Castro LF, Casulari LA \& Azevedo MF. Short-term treatment with cabergoline can lead to tumor shrinkage in patients with nonfunctioning pituitary adenomas. Pituitary 201316 189-194. (doi:10.1007/s11102-0120403-y)

59 Vieira Neto L, Wildemberg LE, Moraes AB, Colli LM, Kasuki L, Marques NV, Gasparetto EL, de Castro M, Takiya CM \& Gadelha MR. Dopamine receptor subtype 2 expression profile in nonfunctioning pituitary adenomas and in vivo response to cabergoline therapy. Clinical Endocrinology 201582 739-746. (doi:10.1111/cen.12684)

60 Zanettini R, Antonini A, Gatto G, Gentile R, Tesei S \& Pezzoli G. Valvular heart disease and the use of dopamine agonists for Parkinson's disease. New England Journal of Medicine 2007356 39-46. (doi:10.1056/NEJMoa054830)

61 Lancellotti P, Livadariu E, Markov M, Daly AF, Burlacu MC, Betea $\mathrm{D}$, Pierard L \& Beckers A. Cabergoline and the risk of valvular lesions in endocrine disease. European Journal of Endocrinology 2008159 1-5. (doi:10.1530/EJE-08-0213)

62 Su Z, Wang C, Wu J, Jiang X, Chen Y, Chen Y, Zheng W, Zhuge $\mathrm{Q}$, Wu Z \& Zeng Y. Expression of dopamine 2 receptor subtype mRNA in clinically nonfunctioning pituitary adenomas. Neurological Sciences 201233 275-279. (doi:10.1007/s10072-0110701-6)

63 Fusco A, Giampietro A, Bianchi A, Cimino V, Lugli F, Piacentini S, Lorusso M, Tofani A, Perotti G, Lauriola L et al. Treatment with octreotide LAR in clinically non-functioning pituitary adenoma: results from a case-control study. Pituitary 201215 571-578. (doi:10.1007/s11102-011-0370-8)

64 Greenman Y \& Melmed S. Expression of three somatostatin receptor subtypes in pituitary adenomas: evidence for preferential SSTR5 expression in the mammosomatotroph lineage. Journal of Clinical Endocrinology and Metabolism 199479 724-729. (doi:10.1210/jc.79.3.724)

65 Taboada GF, Luque RM, Bastos W, Guimarães RF, Marcondes JB, Chimelli LM, Fontes R, Mata PJ, Filho PN, Carvalho DP et al. Quantitative analysis of somatostatin receptor subtype (SSTR1-5) gene expression levels in somatotropinomas and non-functioning pituitary adenomas. European Journal of Endocrinology 2007156 65-74. (doi:10.1530/eje.1.02313)

66 Pawlikowski M, Lawnicka H, Pisarek H Kunert-Radek J, Radek M \& Culler MD. Effects of somatostatin-14 and the receptor specific somatostatin analogs on chromogranin A and alpha-subunit (alpha-SU) release from 'clinically nonfunctioning' pituitary adenoma cells incubated in vitro. Journal of Physiology and Pharmacology 200758 179-188.

67 Zatelli MC, Piccin D, Bottoni A, Ambrosio MR, Margutti A, Padovani R, Scanarini M, Taylor JE, Culler MD, Cavazzini L et al. Evidence for differential effects of selective somatostatin receptor subtype agonists on $\alpha$-subunit and chromogranin-A secretion and on cell viability in human nonfunctioning pituitary adenomas in vitro. Journal of Clinical Endocrinology and Metabolism 200489 5181-5188. (doi:10.1210/jc.2003-031954)

68 Florio T, Thellung S, Arena S, Corsaro A, Spaziante R, Gussoni G, Acuto G, Giusti M, Giordano G \& Schettini G. Somatostatin and its analog lanreotide inhibit the proliferation of dispersed human non-functioning pituitary adenoma cells in vitro. European Journal of Endocrinology 1999141 396-408. (doi:10.1530/eje.0.1410396)

69 Luque RM, Ibáñez-Costa A, Neto LV, Taboada GF, HormaecheaAgulla D, Kasuki L, Venegas-Moreno E, Moreno-Carazo A, Gálvez MÁ, Soto-Moreno A et al. Truncated somatostatin receptor variant sst5TMD4 confers aggressive features (proliferation, invasion and reduced octreotide response) to somatotropinomas. Cancer Letters 2015359 299-306. (doi:10.1016/j.canlet.2015.01.037)

70 Zatelli MC, Piccin D, Vignalli C, Tagliati F, Ambrosio MR, Bondanelli M, Cimino V, Bianchi A, Schmid HA, Scanarini M et al. Pasireotide, a multiple somatostatin receptor subtypes ligand, 
reduces cell viability in non-functioning pituitary adenomas by inhibiting vascular endothelial growth factor secretion. EndocrineRelated Cancer 2007 14 91-102. (doi:10.1677/ERC-06-0026)

71 Lee M, Lupp A, Mendoza N, Martin N, Beschorner R, Honegger J, Schlegel J, Shively T, Pulz E, Schulz S et al. SSTR3 is a putative target for the medical treatment of gonadotroph adenomas of the pituitary. Endocrine-Related Cancer 201522 111-119. (doi:10.1530/ ERC-14-0472)

72 Sharma K, Patel YC \& Srikant CB. Subtype-selective induction of wild-type p53 and apoptosis, but not cell cycle arrest, by human somatostatin receptor 3. Molecular Endocrinology 199610 1688-1696. (doi:10.1210/mend.10.12.8961277)

73 Theodoropoulou M \& Stalla GK. Somatostatin receptors: from signaling to clinical practice. Frontiers in Neuroendocrinology 2013 34 228-252. (doi:10.1016/j.yfrne.2013.07.005)

74 Fleseriu M. Medical treatment of Cushing disease new targets, new hope. Endocrinology and Metabolism Clinics of North America 201544 51-70. (doi:10.1016/j.ecl.2014.10.006)

75 Schmid HA, Brue T, Colao A, Gadelha MR, Shimon I, Kapur K, Pedroncelli AM \& Fleseriu M. Effect of pasireotide on glucoseand growth hormone-related biomarkers in patients with inadequately controlled acromegaly. Endocrine 201653 210-219. (doi:10.1007/s12020-016-0895-8)

76 Rocheville M, Lange DC, Kumar U, Patel SC, Patel RC \& Patel YC Receptors for dopamine and somatostatin: formation of heterooligomers with enhanced functional activity. Science $2000 \mathbf{2 8 8}$ 154-157. (doi:10.1126/science.288.5463.154)

77 Andersen M, Bjerre P, Schrøder HD, Edal A, Høilund-Carlsen PF, Pedersen PH \& Hagen C. In vivo secretory potential and the effect of combination therapy with octreotide and cabergoline in patients with clinically non-functioning pituitary adenomas. Clinical Endocrinology 200154 23-30. (doi:10.1046/j.13652265.2001.01172.x)

78 Klibanski A, Jameson JL, Biller BM, Crowley WF Jr, Zervas NT, Rivier J, Vale WW \& Bikkal H. Gonadotropin and alpha-subunit responses to chronic gonadotropin-releasing hormone analog administration in patients with glycoprotein hormone-secreting pituitary tumors. Journal of Clinical Endocrinology and Metabolism 198968 81-86. (doi:10.1210/jcem-68-1-81)

79 McGrath GA, Goncalves RJ, Udupa JK, Grossman RI, Pavlou SN, Molitch ME, Rivier J, Vale WW \& Snyder PJ. New technique for quantitation of pituitary adenoma size: use in evaluating treatment of gonadotroph adenomas with a gonadotropinreleasing hormone antagonist. Journal of Clinical Endocrinology and Metabolism 199376 1363-1368.

80 Garmes HM, Grassiotto OR, Fernandes YB, Queiroz Lde S, Vassalo J, de Oliveira DM \& Benetti-Pinto CL. A pituitary adenoma secreting follicle-stimulating hormone with ovarian hyperstimulation: treatment using a gonadotropin-releasing hormone antagonist. Fertility and Sterility 201297 231-234. (doi:10.1016/j.fertnstert.2011.10.015)

81 Raverot G1, Sturm N, de Fraipont F, Muller M, Salenave S, Caron P, Chabre O, Chanson P, Cortet-Rudelli C, Assaker R et al. Temozolomide treatment in aggressive pituitary tumors and pituitary carcinomas: a French multicenter experience. Journal of Clinical Endocrinology and Metabolism 201095 4592-4599. (doi:10.1210/jc.2010-0644)

82 McCormack AI, Wass JA \& Grossman AB. Aggressive pituitary tumours: the role of temozolomide and the assessment of MGMT status. European Journal of Clinical Investigation 201141 11331348. (doi:10.1111/j.1365-2362.2011.02520.x)

83 Raverot G, Castinetti F, Jouanneau E, Morange I, Figarella-Branger D, Dufour H, Trouillas J \& Brue T. Pituitary carcinomas and aggressive pituitary tumours: merits and pitfalls of temozolomide treatment. Clinical Endocrinology 201276 769-775. (doi:10.1111/ j.1365-2265.2012.04381.x)
84 Hirohata T, Asano K, Ogawa Y, Takano S, Amano K, Isozaki O, Iwai Y, Sakata K, Fukuhara N, Nishioka H et al. DNA mismatch repair protein (MSH6) correlated with the responses of atypical pituitary adenomas and pituitary carcinomas to temozolomide: the national cooperative study by the Japan Society for Hypothalamic and Pituitary Tumors. Journal of Clinical Endocrinology and Metabolism 201398 1130-1136. (doi:10.1210/ jc.2012-2924)

85 Losa M, Bogazzi F, Cannavo S, Ceccato F, Curtò L, De Marinis L, Iacovazzo D, Lombardi G, Mantovani G, Mazza E et al. Temozolomide therapy in patients with aggressive pituitary adenomas or carcinomas. Journal of Neurooncology $2016 \mathbf{1 2 6}$ 519-525. (doi:10.1007/s11060-015-1991-y)

86 Bengtsson D, Schrøder HD, Andersen M, Maiter D, Berinder K, Feldt Rasmussen U, Rasmussen ÅK, Johannsson G, Hoybye C, van der Lely AJ et al. Long-term outcome and MGMT as a predictive marker in 24 patients with atypical pituitary adenomas and pituitary carcinomas given treatment with temozolomide. Journal of Clinical Endocrinology and Metabolism 2015100 1689-1698. (doi:10.1210/jc.2014-4350)

87 Zhao Y, Xiao Z, Chen W, Yang J, Li T \& Fan B. Disulfiram sensitizes pituitary adenoma cells to temozolomide by regulating O6-methylguanine-DNA methyltransferase expression. Molecular Medicine Reports 201512 2313-2322. (doi:10.3892/ mmr.2015.3664)

88 Dai C, Zhang B, Liu X, Guo K, Ma S, Cai F, Yang Y, Yao Y, Feng M, Bao $\mathrm{X}$ et al. Pyrimethamine sensitizes pituitary adenomas cells to temozolomide through cathepsin B-dependent and caspasedependent apoptotic pathways. International Journal of Cancer 2013133 1982-1993. (doi:10.1002/ijc.28199)

89 Kun Z, Yuling Y, Dongchun W, Bingbing X, Xiaoli L \& Bin X. HIF$1 \alpha$ inhibition sensitized pituitary adenoma cells to temozolomide by regulating presenilin 1 expression and autophagy. Technology in Cancer Research and Treatment 201615 NP95-NP104. (doi:10.1177/1533034615618834)

90 Bergsma H, van Vliet EI, Teunissen JJ, Kam BL, de Herder WW, Peeters RP, Krenning E \& Kwekkeboom DJ. Peptide receptor radionuclide therapy (PRRT) for GEP-NETs. Best Practice and Research Clinical Gastroenterology 201226 867-881. (doi:10.1016/j. bpg.2013.01.004)

91 Maclean J, Aldridge M, Bomanji J, Short S \& Fersht N. Peptide receptor radionuclide therapy for aggressive atypical pituitary adenoma/carcinoma: variable clinical response in preliminary evaluation. Pituitary 201417 530-538. (doi:10.1007/s11102-0130540-y)

92 Komor J, Reubi JC \& Christ ER. Peptide receptor radionuclide therapy in a patient with disabling non-functioning pituitary adenoma. Pituitary 201417 227-231. (doi:10.1007/s11102-0130494-0)

93 Sun LC \& Coy DH. Somatostatin receptor-targeted anti-cancer therapy. Current Drug Delivery 20118 2-10. (doi:10.2174/1567201 11793663633)

94 Lelle M, Kaloyanova S, Freidel C, Theodoropoulou M, Musheev M, Niehrs C, Stalla G \& Peneva K. Octreotide-mediated tumortargeted drug delivery via a cleavable doxorubicin-peptide conjugate. Molecular Pharmacology 201512 4290-4300. (doi:10.1021/acs.molpharmaceut.5b00487)

95 Ledermann JA, Canevari S \& Thigpen T. Targeting the folate receptor: diagnostic and therapeutic approaches to personalize cancer treatments. Annals of Oncology 201526 2034-2043. (doi:10.1093/annonc/mdv250)

96 Evans CO, Reddy P, Brat DJ, O'Neill EB, Craige B, Stevens VL \& Oyesiku NM. Differential expression of folate receptor in pituitary adenomas. Cancer Research 200363 4218-1424.

97 Liu X, Ma S, Yao Y, Li G, Feng M, Deng K, Dai C, Cai F, Li Y, Zhang $\mathrm{B}$ et al. Differential expression of folate receptor alpha in pituitary 
adenomas and its relationship to tumor behavior. Neurosurgery 201270 1274-1280. (doi:10.1227/NEU.0b013e3182417e76)

98 Liu X, Ma S, Dai C, Cai F, Yao Y, Yang Y, Feng M, Deng K, Li G, $\mathrm{Ma} \mathrm{W}$ et al. Antiproliferative, antiinvasive, and proapoptotic activity of folate receptor $\alpha$-targeted liposomal doxorubicin in nonfunctional pituitary adenoma cells. Endocrinology $2013 \mathbf{1 5 4}$ 1414-1423. (doi:10.1210/en.2012-2128)

99 Galt JR, Halkar RK, Evans CO, Osman NA, LaBorde D, Fox TH, Faraj BA, Kumar K, Wang H \& Oyesiku NM. In vivo assay of folate receptors in nonfunctional pituitary adenomas with $99 \mathrm{mTc}-$ folate SPECT/CT. Journal of Nuclear Medicine 201051 1716-1723. (doi:10.2967/jnumed.108.061689)

100 Dworakowska D, Wlodek E, Leontiou CA, Igreja S, Cakir M, Teng M, Prodromou N, Góth MI, Grozinsky-Glasberg S, Gueorguiev $\mathrm{M}$ et al. Activation of RAF/MEK/ERK and PI3K/AKT/mTOR pathways in pituitary adenomas and their effects on downstream effectors. Endocrine-Related Cancer 200916 1329-1338. (doi:10.1677/ERC-09-0101)

101 Monsalves E, Juraschka K, Tateno T, Agnihotri S, Asa SL, Ezzat S \& Zadeh G. The PI3K/AKT/mTOR pathway in the pathophysiology and treatment of pituitary adenomas. Endocrine-Related Cancer 201421 R331-R344. (doi:10.1530/ERC-14-0188)

102 Noh TW, Jeong HJ, Lee MK, Kim TS, Kim SH \& Lee EJ. Predicting recurrence of nonfunctioning pituitary adenomas. Journal of Clinical Endocrinology and Metabolism 200994 4406-4413. (doi:10.1210/jc.2009-0471)

103 Jia W, Sanders AJ, Jia G, Liu X, Lu R \& Jiang WG. Expression of the mTOR pathway regulators in human pituitary adenomas indicates the clinical course. Anticancer Research 201333 3123-3131.

104 Rubinfeld H \& Shimon I. PI3K/Akt/mTOR and Raf/MEK/ERK signaling pathways perturbations in non-functioning pituitary adenomas. Endocrine 201242 285-291. (doi:10.1007/s12020-0129682-3)

105 Zatelli MC, Minoia M, Filieri C, Tagliati F, Buratto M, Ambrosio MR, Lapparelli M Scanarini M \& Degli Uberti EC. Effect of everolimus on cell viability in nonfunctioning pituitary adenomas. Journal of Clinical Endocrinology and Metabolism 2010 95 968-976. (doi:10.1210/jc.2009-1641)

106 Lee M, Wiedemann T, Gross C, Leinhäuser I, Roncaroli F, Braren R \& Pellegata NS. Targeting PI3K/mTOR signaling displays potent antitumor efficacy against nonfunctioning pituitary adenomas. Clinical Cancer Research 201521 3204-3215. (doi:10.1158/10780432.CCR-15-0288)

107 Cerovac V, Monteserin-Garcia J, Rubinfeld H, Buchfelder M, Losa M, Florio T, Paez-Pereda M, Stalla GK \& Theodoropoulou M. The somatostatin analogue octreotide confers sensitivity to rapamycin treatment on pituitary tumor cells. Cancer Research 201070 666-674. (doi:10.1158/0008-5472.CAN-09-2951)

108 Jouanneau E, Wierinckx A, Ducray F, Favrel V, Borson-Chazot F, Honnorat J, Trouillas J \& Raverot G. New targeted therapies in pituitary carcinoma resistant to temozolomide. Pituitary 201215 37-43. (doi:10.1007/s11102-011-0341-0)

109 O'Reilly MW, Reulen RC, Gupta S, Thompson CA, Dineen R, Goulden EL, Bugg G, Pearce H, Toogood AA, Gittoes NJ et al. ACTH and gonadotropin deficiencies predict mortality in patients treated for nonfunctioning pituitary adenoma: long-term follow-up of 519 patients in two large European centres. Clinical Endocrinology 201685 748-756. (doi:10.1111/ cen.13141)

110 Zueger T, Kirchner P, Herren C, Fischli S, Zwahlen M, Christ E \& Stettler C. Glucocorticoid replacement and mortality in patients with nonfunctioning pituitary adenoma. Journal of Clinical Endocrinology and Metabolism 201297 E1938-E1942. (doi:10.1210/ jc.2012-2432)

111 Dekkers OM, van der Klaauw AA, Pereira AM Biermasz NR, Honkoop PJ, Roelfsema F, Smit JW \& Romijn JA. Quality of life is decreased after treatment for nonfunctioning pituitary macroadenoma. Journal of Clinical Endocrinology and Metabolism 200691 3364-3369. (doi:10.1210/jc.2006-0003)

112 van der Klaauw AA, Kars M, Biermasz NR, Roelfsema F, Dekkers OM, Corssmit EP, van Aken MO, Havekes B, Pereira AM, Pijl $\mathrm{H}$ et al. Disease-specific impairments in quality of life during long-term follow-up of patients with different pituitary adenomas. Clinical Endocrinology 200869 775-784. (doi:10.1111/j.13652265.2008.03288.x)

113 Capatina C, Christodoulides C, Fernandez A, Cudlip S, Grossman AB, Wass JA \& Karavitaki N. Current treatment protocols can offer a normal or near-normal quality of life in the majority of patients with non-functioning pituitary adenomas. Clinical Endocrinology 201378 86-93. (doi:10.1111/j.13652265.2012.04449.x)

114 Karppinen A, Ritvonen E, Roine R, Sintonen H, Vehkavaara S, Kivipelto L, Grossman AB, Niemelä M \& Schalin-Jäntti C. Health-related quality of life in patients treated for nonfunctioning pituitary adenomas during the years 2000 2010. Clinical Endocrinology 201684 532-539. (doi:10.1111/ cen.12967)

115 Ntali G, Capatina C, Fazal-Sanderson V, Byrne JV, Cudlip S, Grossman AB, Wass JA \& Karavitaki N. Mortality in patients with non-functioning pituitary adenoma is increased: systematic analysis of 546 cases with long follow-up. European Journal of Endocrinology $2016 \mathbf{1 7 4}$ 137-145. (doi:10.1530/EJE15-0967)

116 Lindholm J, Nielsen H, Bjerre P, Christiansen JS, Hagen C, Juul S, Jørgensen J, Kruse A, Laurberg P \& Stochholm K. Hypopituitarism and mortality in pituitary adenomas. Clinical Endocrinology 2006 65 51-58. (doi:10.1111/j.1365-2265.2006.02545.x)

117 Olsson DS, Bryngelsson IL \& Ragnarsson O. Time trends of mortality in patients with non-functioning pituitary adenoma: a Swedish nationwide study. Pituitary 201720 218-224. (doi:10.1007/s11102-016-0764-8)

Received 15 March 2017

Revised version received 25 April 2017

Accepted 3 May 2017 